\title{
Megaprojects, epistemological violence and environmental conflicts in Brazil
}

\author{
Andréa Zhouri * \\ UNIVERSIDADE FEDERAL DE MINAS GERAIS (UFMG), BRASIL
}

\begin{abstract}
Characterized as 'social effects of large projects', it is common across multiple national contexts that involuntary displacement and forced resettlement are dealt with by means of a managerial perspective within the ecological modernization paradigm. I understand this approach as a type of epistemological violence that acts to dismiss other forms of perceiving and being in the world. It imposes a standardization of the social fabric as conditions to make subjects legible and governable. Through the lens of epistemological violence, I focus on the logic that justifies space interventions in relation to the consequences on the ground that perpetuate environmental inequalities in Brazil. Ideas such as sustainable development have produced a colonizing effect when associated to specific processes on the ground. The analyses calls attention to the invisibility of peasants lives and knowledge systems under the licensing process of hydroelectric power plants, and how epistemological violence results in physical violence via displacement in situ.
\end{abstract}

Keywords: Megaprojects, epistemological violence, environmental conflicts, Brazil

\section{Resumen}

Caracterizado como "efectos sociales de grandes proyectos", es común en múltiples contextos nacionales que el desplazamiento involuntario y el reasentamiento forzado se aborden mediante una perspectiva gerencial dentro del paradigma de la modernización ecológica. Entiendo este enfoque como un tipo de violencia epistemológica que actúa para descartar otras formas de percibir y estar en el mundo. Así se impone una estandarización del tejido social como condiciones para hacer que los sujetos sean legibles y gobernables. A través del lente de la violencia epistemológica, me centro en la lógica que justifica las intervenciones espaciales en relación con las consecuencias sobre el terreno que perpetúan las desigualdades ambientales en Brasil. Ideas como el desarrollo sostenible han producido un efecto colonizador cuando se asocian a procesos específicos en el terreno. El análisis llama la atención sobre la invisibilidad de las vidas de los campesinos y los sistemas de conocimiento bajo el proceso de concesión de licencias de las centrales hidroeléctricas, y cómo la violencia epistemológica resulta en violencia física a través del desplazamiento in situ.

Palabras Claves: Megaproyectos, violencia epistemológica, conflictos ambientales, Brasil.

*azhouri@gmail.com 
he organization of Brazil's energy grid concentrates its generating capacity on the exploitation of the country's 1 hydrologic potential. The expansion of hydrologic generating capacity - a strategic component of the plan of national economic growth $(\mathrm{PAC})-$ is a response to the growing demand of electricity-intensive sectors. These sectors are crucial within the overall economic policy, which aims to place the country in the world market by means of commodity export. The result is the multiplying of dams, including the revival of old projects, such as the Belo Monte project in the Amazonian state of Pará. According to Silva and Rothman (2011: 729), the PAC includes 67.3 billion Euros in public and private investment in hydroelectric power generation. The principal investments, in accordance to the original details laid out in the PAC, were to be in Amazonia and the southeastern state of Minas Gerais. In 2007 there were 210 hydroelectric dams in operation in Minas Gerais and the Programa de Geração Hidrelétrica em Minas Gerais (Hydroelectric Generation Program of Minas Gerais, PGHMG) proposed the construction of 380 additional plants during the period 2007-27 (See Figure 1), of which 45 would be large dams and 335 would be of small or medium proportions (Silva \& Rothman, 2011: 729).

Figure i - The Brazilian state of Minas Gerais.

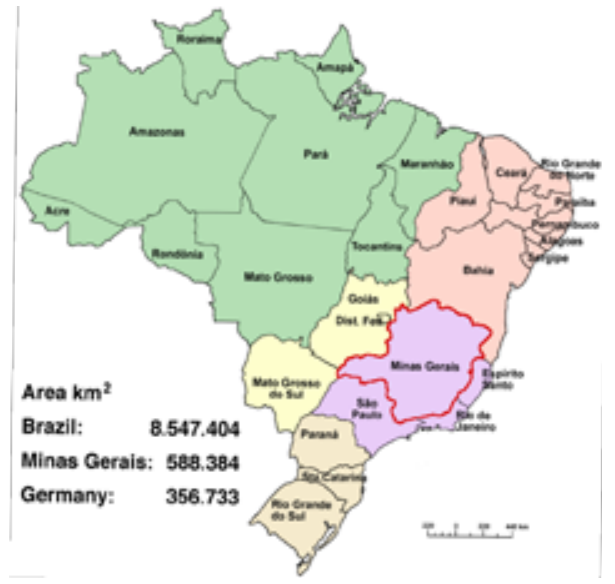


Figure 2 - Minas Gerais has 2 I O DAMS IN OpERATION AND THERE ARE PLANS FOR THE CONSTRUCTION OF 380 MORE.

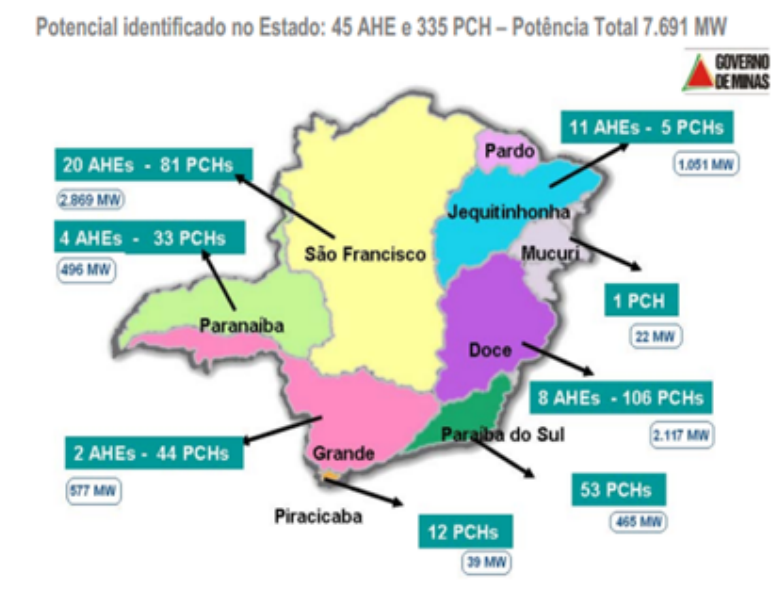

FONTE: www. sede.mg govibr.

Such projects attract attention not only for the volume of resources mobilized but also for their significant and widely known socio-environmental impacts: involuntary displacement of local populations (Bloemer, 2001; Oliver-Smith, 2006; 2008; Rothman, 2008); loss of large areas of fertile land (Sigaud et al., 1987); interruption of ongoing local economic activities; elimination of native vegetation; alteration of the entire aquatic environment; as well as impacts on human health by the dissemination of vectors which transmit diseases and by the deterioration of water quality (Najar, 1990; Costa, 1991; Couto, 1999). These effects are aggravated by the sequential construction of multiple dams within the same river basin, producing cumulative impacts. In the Jequitinhonha Valley, for instance, in the semi-arid region of Minas Gerais, the Information System of Brazilian Hydroelectric Potential identifies at least twenty inventoried projects, with prospects for multiple displacements as a result of the transformation of the local environment.

Characterized as 'social effects of large projects', it is common across multiple national contexts that involuntary displacement and 
forced resettlement (Oliver-Smith, 2006) are dealt with by means of a managerial perspective, where 'externalities' are to be identified, measured, internalized and efficiently managed by programs of risk-mitigation and compensation. Such a managerial approach is central to the ecological modernization paradigm and represents a form of epistemological violence that acts to dismiss other forms of perceiving and being in the world (Zhouri, 2014). Therefore, a critical analyses of the processes set in train by involuntary displacement suggests the need to understand them as a particular form of population movement in space, marked by a dynamic which interlaces violence with the production of conforming and legible subjects. That is, State interventions for the ordering of space with the classification of possible, legitimate and desirable uses implies a capacity of control over the subjects and their respective territories (Scott, 1998: 2). The rationalization and standardization of the social fabric are thereby imposed as conditions to make it legible and governable. I propose to discuss this rationalization of space through the lens of epistemological violence, focusing on the logic that justifies space interventions in relation to the consequences on the ground that perpetuate environmental inequalities in Brazil.

In order to develop my argument, this article has been organized in three main sections. In the first section, I discuss how epistemological violence, which finds its most visible effects at the local level, operates from the start within the logic of the environmental impact assessment process. This process is understood as an operational mechanism of the global ecological modernization paradigm consolidated since the 1970s and 1980s. I argue that ideas such as sustainable development, sustainability and its related participatory principle, have produced a colonizing effect when associated to specific processes on the ground. Following this discussion, the other two sections focus on the implications of such global ideas and related mechanisms upon local ecological and socio-economic processes through the case study of communities affected by a hydroelectric power plant in the Jequitinhonha Valley, Minas Gerais. The analyses calls attention to the invisibility of 
peasants lives and knowledge systems under the licensing process, and how epistemological violence results in physical violence via displacement in situ. A technical controversy embedded in the process environmental assessment underlines epistemological violence as a cascade effect that dismisses both expert knowledge from the Social Sciences and the traditional knowledge held by local peoples. The result is the silencing of local peoples voices and the aggravation of social and environmental inequalities in Brazil.

Environmental Impact Assessment under the Global Governance Package

The ecological modernization paradigm (Blowers, 1997) became operational in Brazil with the institutionalization of environmental issues during the 1970s and 1980s. This process was largely grounded in global ideas about sustainability and sustainable development, which were disseminated after the Rio Summit of 1992. Still widely acknowledged today, a key theme concerned the need for participatory management to reconcile economic, environmental and social interests (Sachs, 2001; Escobar, 1995). The paradigm was in effect a form of environmentally-related adjustment (or 'modernization') of classical development. Technical prevention of so-called environmental impacts as well as adoption of mitigation and compensation measures for environmental degradation both set the tone for the new policy. Rendering sustainable development strategies operational required the implementation of a new multiscale regulatory framework. In Brazil, environmental campaigns in the 1970s and 1980s against World Bank loans for road building and other megaprojects in the Amazon Rainforest forced the Bank to undergo reforms. As a result, environmental impact assessment mechanisms, enforcement of specific environmental legislation, and emphasis on environmental education were components largely underwritten by international financial institutions. Following environmental critique, corporations invested in new technologies aiming at ecological efficiency, whereas action focused on the socialenvironmental responsibilities of firms included calls for dialogue 
and the construction of 'partnerships' with civil society groups. In this way, a process of consensus building became central to efforts to tame the environmental critique at that time in order to make the proposed sustainable development possible (Zhouri, 2004). In this scenario, the legal infrastructure for environmental licensing was legislated. As set out in federal resolution Conama 001/1986 and Conama 237/1997, this governance infrastructure involves progressive negotiation through evaluation of three successive licenses that would assure compliance with the technical and legal requirements of projects.

In practice, however, conflicts prevail as the licencing process is marked by a differential distribution of power in which social groups in dispute each have their visions, values and discourses shaped by the social place from where they are pronounced. As a field (Bourdieu, 1993), environmental licensing structures relations among these agents, defining for them the terrain and the possibilities for action. The unequal distribution of economic, political and symbolic capital locates agents within the field, providing distinct powers to enunciate and assert claims to their respective political projects. One of the main kinds of capital within the environmental field is technical expertise. Local peoples affected by projects, such as peasants and riverside dwellers, have little this kind of capital compared to the engineers, lawyers and other types of experts hired by project proponents. As these experts set about determining potential impacts and mitigation measures, as well as the possibility of compensation for damages and risks, affected communities cannot mount similarly technical arguments in defense of their territories and modes of livelihood. This is not because these communities lack knowledge about their ecological and socioeconomic circumstances, but rather because risks and damages are usually defined according to Western epistemologies. Therefore, paradoxically, participation ends up enabling the legitimation of decisions that reproduce the doxa-or grounding assumptionsof the field defined by environmental licensing and sustainable development. Public hearings are performed, but they are acts that 
reinforce the domain of Western knowledge, especially the hard sciences in detriment of social sciences and the local epistemologies in different degrees and scales, as I shall discuss further bellow.

As these arguments suggest, the participatory principle of the new global environmental paradigm was embedded as just one more item in a larger process of environmental management. The latter was really about technical practices within market-oriented initiatives. For instance, as I have discussed in previous work (Zhouri, 2004), Amazon campaigns in Europe shifted during the 1990s from resistance to consensus building. A boycott of timber imports was replaced by certification schemes involving close cooperation between NGOs and timber companies, most notably demonstrated in the creation of the Forest Stewardship Council (FSC). Hence, within the global governance package, participation seems to have mainly addressed "civil society", that is, "organized" groups that are legible to governments and funders. These groups are "qualified" agents, since unlike local communities they are able to marshal the social capital required to make their voices heard in the environmental field. Their qualifications include technical expertise, project-writing skills, Western institutional organization, computer skills and knowledge of English. Most Brazilians, especially those living in rural areas or on the periphery of cities, have thereby been excluded. In this sense, following Rancière (1996) and Mouffe (1999), we can conclude that the consensus building strategy, which was global in scale, in many ways erased difference and dissent. That is, a political dimension of conflict was eschewed in favor of a liberal conception of competition between individual interested parties, whose interests could be balanced through limited compromise.

The managerial perspective which prevailed implied an understanding of the environment as a reality separate from society (as a locus of 'the natural'). As has already been discussed elsewhere (Zhouri \& Oliveria 2006; Carneiro, 2005; Acselrad et al., 2004; among others), the language of impact, which became hegemonic within environmental discourses and practices since then, presupposes the environment as an objective reality. As an object 
independent from society, the environment is to be analyzed in the light of Western scientific knowledge and technical assessment. As a consequence, other epistemologies and knowledges are disregarded as illegitimate perceptions and discourses within the environmental field, a fact that contributes to the increase of inequalities and the perpetuation of the coloniality of knowledge and power (Quijano, 2002; Mignolo, 2004; 2008). Indeed, the growing influence of the ecological modernization paradigm - which in Brazil refers mainly to growth via the export of commodities - did not lead to the reduction of expropriating mechanisms (Berno de Almeida et al., 2010). The loss of land and environmental resources continues to affect the most vulnerable social groups, increasing not only inequalities but also environmental conflicts. This seems to be a trend not only in Brazil, but in Latin America more generally, as many testimonies and reports presented at the VI Meeting of the Waterlat Network (Manizales, October 2014) have demonstrated.

The hegemonic paradigm, adopted by major sectors of the State and corporations, defends consensus and understands conflict as a negative force to be resolved. Nevertheless, people affected by dams and other 'development' projects seem to understand conflict as a necessary part of political action when their voices are not heard. In the face of the economic and expansionist objectives of the State, the struggles of communities affected by dams (and also mining, as discussed in Zhouri, 2014) embodies the right to selfdetermination, that is, the right of the collective to determine the future of its territories. At least two competing rationalities can be underlined here: (a) that of the riverside dwellers, who view the land as communal and family heritage defended by collective memory and by rules of resource use and sharing, and (b), that of sectors of the State and corporations (public and private entrepreneurs) who, from a market perspective, view land as property and therefore as a valuable commodity. In this battlefield, where the different positions hold uneven political, economic and social capitals (Bourdieu, 1993), unsustainable and unequal social and environmental policies are perpetuated, as in the controversial case presented bellow. 
Who is AFFeCTED BY A DAM? A CASE OF DisplaCEMENT IN SITU In general, a "patrimonialist" logic prevails in the environmental licensing process, which transforms subjects with their intricate networks of social and environmental relations into numerical units based on population or habitation. According to the procedures of most Environmental Impact Assessment (EIA) process, the analysis of the social reality affected by a specific project is based on the project needs itself, focusing for instance on the immediate area planned to be flooded by the reservoir of a hydroelectric dam. Hence, the people identified as affected are only those who live in that particular area. These studies thus do not consider 'the localities' of the project in a well-rounded manner (Appadurai, 2004), effacing the material and cultural realities of 'place' (Escobar, 2001) that shape local community organizations and 'ecosystems'. Defining the universe of atingidos (affected individuals and communities) instead depends on abstract planning and budget schedules established by official agencies and private companies. If development is thereby to be understood as a governmental project coordinated by the State aiming to produce governable subjects ( $\mathrm{Li}, 1999)$, then notions of legibility and population become central. The latter is the object, means and end of development, but to manage it, first it must be made legible. Who then is affected by a dam and how? Who sets the boundaries? From what point of view? An ethnographic case study may help to shed light on these questions.

The Jequitinhonha Valley, located in the Brazilian state of Minas Gerais, is considered one of the poorest regions of the country. As such, it is widely known as "Vale da Miséria", that is, the Valley of Misery, especially by the elites and local politicians throughout decades. Given this condition, it has been the target of developmental policies, especially since the 1970s. A variety of projects have transformed the diverse landscapes of the ecosystem of the cerrado, caatinga and mata atlântica into industrial settings of eucalyptus monocultures and hydroelectric dams. Justified and legitimated by the images of stagnation and absolute poverty imposed on the valley, 
current proposals for the implementation of further hydroelectric dams retain this messianic project of salvation (Zhouri and Oliveira, 2009). The Irapé Hydroelectric Plant for example, despite 17 years of opposition, was inaugurated in 2005 on the Jequitinhonha River. The dam is 209 meters high, the tallest in Latin America, with a reservoir covering $137,160 \mathrm{~km}^{2}$ in a region of irregular rainfall (the semi-arid). The dam affects seven municipalities and has displaced approximately 1.124 families - around 5,000 people. The license for construction was granted in 2002, despite an unfavourable technical opinion of the State Environmental Agency (FEAM), which cited non-compliance with 47 environmental and social special conditions that had been applied by the Power Utility of Minas Gerais State (CEMIG). The Murta dam is another project on the same river, downstream from Irapé. It has not yet been built, but threatens to promote similar impacts in the region.

Both projects demonstrate the problem of conflicting rationalities concerning the meanings of land: on the dwellers side, land is place, that is, a territory of collective appropriation as well as family heritage. On the side of companies, land is space, in the form of resource or private property, both modes eligible for capital appropriation. This second rationality is clearly evident in the environmental impact assessment study (EIA) of the Murta dam. Besides presenting a considerable amount of technical faults and lack of consistency - such as the precise size of the area to be flooded and the exact number of communities to be affected - the study employs meanings and judgements that clearly diminish the value of people and their land. A statement extracted from the EIA may well illustrate a broader view of how corporations understand the people and their places in the Jequitinhonha Valley, "o vale da miséria". In its discussion of the impacts of the dam, particularly the displacement of communities, the EIA notes that "The properties are subject to involuntary migration” (D'alessandro \& Associados, 2001). What is the subject of this sentence? What does it mean to be a "subject of involuntary migration"? Firstly, It is worth noting that there are no people in this statement. The focus is on the properties, which 
are passively objects of "involuntary migration", as they are devalued in market terms. Subjects are thereby reduced to properties, with a consequently disparaging evaluation, which alludes to a particular conception of poverty, meaning lack of monetary income, failure to fulfill certain requirements that matter for GDP figures, a life style that is not adequately modern, and so on (Zhouri \& Oliveira 2006). If we compare this view to that of the people affected by the dams, we find that they reject this logic that denies them their condition as subjects and, above all, as subjects of rights. In the case of the Irapé Dam, the dam-affected people produced, by means of the language of the cordel, a type of counter-EIA which is partly reproduced bellow:

[...] Ladies and gentlemen those of you who are not familiar with the north of Minas Gerais, pay attention to this true story. It was made completely with the people and many of their communities, research which lasted several days to discover the truth [...] It is a wholesome place where we were born and raised and live since the time of our most backward grandfathers [...] Those who think that everything here is the same are sadly mistaken; at each stretch of the river, every person is different. Everyone has his own system of weeding, planting and harvesting; the ways they do it are different; it's not easy to understand. [...] Anyone who thinks that the people are all alike are mistaken [...] They [the dam entrepreneur] just don't see the differences; they mix the atheist with the faithful, the strong with the weak, those who have teeth with the toothless [...] (Cordel of the Dam-Affected People, 1997)

The excerpt makes claims to the voice and specific knowledge of the local people, normally effaced by technical studies, such as the EIA. It implicitly denounces the epistemological violence that renders a multiplicity of subjects and their diverse modes of living into standard numbers and statistics legible for the calculation of mitigation measures. Meanwhile, if communities that are located in the area to be flooded by a dam project are transformed into numbers as affected people, those who are located downstream of the reservoir do not even enter into the calculations of experts, as they are not considered to be affected by the dam. It is to this issue 
that I turn next.

In early 2006, right after the start of Irapés operation, our research team was confronted with a critical situation involving local dwellers downstream from the Irapé dam. They reported that at the time Irapé was opened, the water of the Jequitinhonha river had a very unpleasant odor, and most people were suffering with skin and eye allergies. Women who washed clothes in the river complained that the water left rust stains on their clothes and that even livestock refused to drink that water. Hence, they asked the team of the Environmental Research Group (GESTA-UFMG) to report their situation to the Public Ministry (Public Prosecutor), so that authorities would provide a solution to restore their environmental conditions. We collected samples of the river water for laboratory analysis and, after reporting alterations detected to the Public Ministry, a legal procedure to investigate the case and attribute responsibilities was initiated.

Within this context, as was usually done in such cases, a wellknown expert - a sanitation engineer - was named by the Public Ministry. The expert analysed documents of the lawsuit and data from the longitudinal studies performed by IGAM (Institute of Water Management of Minas Gerais) to monitor water quality. His report referred to a federal regulation (Conama Resolution 357/05) which presents a typology that places the water of the Jequitinhonha river as 'class 2', that is, water of 'good quality'. From his viewpoint, complaints and questions raised by local communities were not the responsibility of the company or within the company's jurisdiction, since 'the waters of the Jequitinhonha river were ureated and already unfit for human consumption prior to the installation of the Irapé dam' (Sperling, 2011). Furthermore, from his viewpoint, the State 'was obligated to safeguard multiple water usages' and water resource management should have the participation of public authorities, of users and of local communities, in accord with the National Policy of Water Resources Management (Sperling, 2011). Therefore, by quoting a general norm, at the same time as playing with images and meanings of the Jequitinhonha valley as a place of scarcity, the 
expert assumed there was no fault caused by the dam company, transferring, thus, to the state and to the local communities, the responsibility for (the lack of) water management.

This case illustrates how the differential positions of social actors may render meanings of the environment (and of environmental problems) very differently. The case depicts the views and implications of at least two diverse actors: on one side, riverine dwellers, who never had sanitation from COPASA (Company of Sanitation in Minas Gerais). Because they use water directly from the river, they felt the changes in the water literally on their skins. On the other side, we have the expert in sanitation who, from a technical and 'objective' analysis - and as an urban citizen who was brought up in a social class that has access to treated water and public sanitation - attributes use of the water from the river to the ignorance of the local population. Hence, for the sanitation expert, claims of riverine dwellers would not correspond to technical evidence legitimated by the competent institutions, and therefore should not be considered by the environmental agencies. This brief account suggests that perceptions of the environment and environmental ideas and practices should be analysed considering the socialization of subjects during their life course as well as the primacy of science in our society, among other aspects (Bourdieu, 1993).

These competing understandings constituted a socio-technical controversy. Not yet convinced by arguments presented by the official expert, the Public Ministry asked GESTA (as technical advisor to the affected population) to return to the area, some five years after presenting the complaints to the Public Ministry, to update information on the ground. Fieldwork was conducted in May 2011 and new information, especially regarding direct and indirect usage of the river water, was produced by GESTA-UFMG. This follow-up research, results of which are summarized in our 2011 report (Gesta, 2011), revealed that the impacts of the dam for the riverine dwellers go far beyond an issue of water quality. In fact, that research documented how local livelihoods are intimately linked to the river ecosystem, and how a specific way of life is in turn 
reflected in a particular epistemology. Both the way of life and the associated epistemology are denied by the hegemonic epistemology and system of power relations.

The analysis of the interaction of these communities with local ecological conditions, particularly the fluvial waters of the Jequitinhonha River, highlights the dependence of the productive organization of families upon the availability of hydric resources, especially the natural rate of flow of the Jequitinhonha River. Riverine dwellers live under a very complex system of vazante agriculture. Vazante is the area located along the margins of the great rivers (Jequitinhonha, Salinas and Vacaria). It is subject to seasonal flooding. Diverse vegetables and greens, such as lettuce, cabbage, onion, garlic, tomato, potato, carrots, pumpkin, among others, are grown in the vazantes. This crop system is comprised of three key parts. First are the baixa, flooded depressions that retain moisture, Second are the tabuleiros, which are higher and more well-drained areas. In the baixas and tabuleiros are the roças, the cultivation areas where the mantimentos (staple or subsistence crops) are grown, such as maize, beans and sometimes rice. The third part of the agricultural topography is that of the chapadas, which are flatter and higher areas, where the soil is sandy and which are now occupied by extensive monoculture eucalyptus plantations. In the past, however, they were used for free-range cattle raising on common lands, as well as the gathering of fruits and other plants of the cerrado. Vazantes, tabuleiros and chapadas constitute distinct, but fundamentally complementary, ecological units, whose different potentialities result in the temporality of a unique landscape in which roças, hortas and mangas alternate.

The flow of the activities of work and the seasonal ecological crop rotations are interrelated, producing living conditions inseparable from relations that the people have with their surroundings.

We underline, then, the practices and knowledge that compose a sophisticated system of resource use with a fine adjustment between ecological capacities of the areas and the potential production of household groups. It is in this way that the organization of spaces and classification 
of the environment are related to factors such as: soil qualities and its adequacy for particular crops, the agricultural calendar and seasonal variation in rainfall, availability of the domestic labour force, as well as the capacity to allocate crops in accord with the current family necessities (Zhouri and Oliveira, 2012).

The control, use and management of the land and its resources is carried out by means of practical knowledge. This savoir-faire is developed over time through direct perceptive engagement with the environment; it is a knowledge constituted within a singular temporality given by the inter-relation and the continuous adjustment between the flow of the waters and the dynamic of labour and production. In this sense, it is the alternations and regularities of the hydrological cycle which order family labour, instituting temporal frames for the organization of productive activities. If subject and environment are mutually constituted here, knowing the landscape is knowing oneself; farming at the edge of the river becomes a matter of self-recognition.

Six years after the opening of the Irapé dam, our fieldwork showed us that changes in the natural rate of flow of the river had resulted in the loss of the most important areas for vazante agriculture.

Figure 3 - Planting on the river bank (vazante), May 2005. Village of Prexedes. Source, GESTA-UFMG

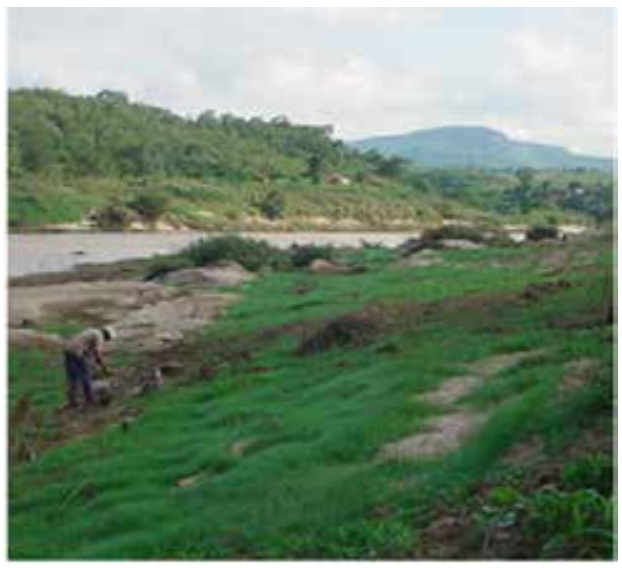


Figure 4 - River bank in 2011. Mud and loss of the Vazante. Village of Prexedes. Source, GESTA-UFMG

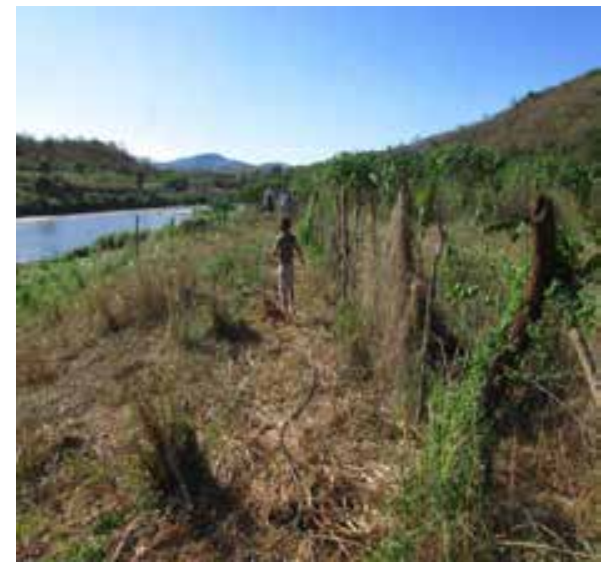

Without regular flooding, the riverine dwellers must depend on rainfall for agricultural production on the tabuleiros, which produces restrictive effects on the family economy. The domain of the vazantes had constituted a productive space that did not rely on rainfall, providing above all what dwellers call "agricultura certa" (guaranteed cultivation). The loss of this domain compromises the fundo de manutenção, a type of family saving represented by the land itself, generating a condition of socio-economic vulnerability as a result of the de-structuring of the ecological equilibrium. Hence, The extinction of the vazantes results in the disarticulation of the peasant farm, as it had previously functioned in the Middle Jequitinhonha, as well as de-structuring other activities such as mining for gemstones in the river and animal raising (Zhouri et al., 2010). Such changes produce a direct impact on the nutritional diet of dwellers, since many do not have any way to increase access to paid labour or other income. These transformations more generally affect the autonomy of the families, as manifested in the manner in which they manage and control the conditions of production within the domestic group (Zhouri et al., 2010).

In these ways, the dam seriously altered a specific model of 
family farm organization. This model was based on practices and knowledges developed in strict and continuous interaction with the environment and its different, though complementary, potentialities. The riverine communities of the Jequitinhonha Valley clearly possess a profound knowledge of their environment as applied to the articulation of spaces and the structuring of productive activities. It is the management of their activities in accord with the spatial-temporal ordering of the river's hydrological processes which guarantees the allocation of labour and provides food during the entire year. Prevented from being guided by the flow of the river, dwellers try to understand once again a landscape which is taking shape in a manner unknown to them and against their will, interrupting and displacing their spaces of life and work.

Given these conditions, the technical expert's conclusion that restoration of an 'ecological rate of flow' of the river eliminates the blame for damage to the downstream population is shown to be flawed in the light of ethnographic data. For the families, and considering their model of social and productive organization, the damage and the problems persist in that they refer not to the restitution of 'an ecological rate of flow', but rather to the transformation of the very ebb and flow of the river, which makes social reproduction impossible according to their traditional epistemological parameters.

GESTA's report, filed within the legal process that ensued (ACP 2006.38.13.012165-7), concludes then that there is a clear causal link between Irapés operation and the vulnerability of downstream affected people. It identifies the situation as a case of displacement in situ (Feldman et al., 2003: 9). An apparent contradiction in terms, the notion of displacement in situ reveals that groups can experience pervasive impacts of development processes in their social and natural landscapes even when they themselves are not displaced to new locations. Therefore, displacement in situ refers to processes in which people remain in their place, but have their conditions of existence significantly altered, modifying their social position, especially their conditions of vulnerability and risk. In this 
way, involuntary displacement might be seen to refer not only to the relocation of populations, but also to the physical transformation of space that also serves to dislocate socio-environmental relationships. Such dislocation engenders relations of inclusion and exclusion through which people lose access and control over their conditions of existence and social reproduction, including natural and material resources, housing, security, solidarity networks, confidence and kinship (Feldman et al., 2003). This process entails epistemological and material violence, since systems of knowledge and modes of living are intertwined and enmeshed in networks of power relations. In this ethnographic case, riverside dwellers's knowledge comes into direct relation with the knowledge of engineers, anthropologists and legal authorities.

\section{KNOWLEDGE, HIERARCHIES AND VIOLENCE}

The legal process ensued in 2006 with the first report to the Public Ministry about the situation observed by the GESTA team's observations in the Jequitinhonha Valley. It was not until 2013, two years after GESTA's second report, that a judge's decision finally came down. That decision concludes that the villagers downstream Irapé were not affected by the dam. In his statement, the federal judge sentenced:

Despite the brilliant report produced by GESTA.... what is observed is that the report has a much more Sociological and Anthropological content rather than a technical approach. It is broader than the object matter on trial. The group lacks, as reported by the official expert, researchers or experts in water quality and environmental impacts provoked by dam building (emphasis added).

It is interesting to highlight a few aspects from this excerpt. Firstly, the judge cannot deny the quality of the report. Nonetheless, he proceeds to disqualify it by a) denying a technical character to Anthropology and Sociology; b) considering it broader than expected, that is, not specifically 'environmental'; c) dismissing the expertise of the authors in accordance with the sanitation engineer's (the nominated expert's) critique. The underpinning aspect to call to 
attention concerns the separation between social and environmental "dimensions", which leads to the hierachization of the production of knowledge from (top) "hard" to (low) "soft" sciences. That separation and hierachization of Western knowledge resonates with the separation between society and nature, and exemplifies an epistemological violence that, by a sort of domino effect, silences other types of production of knowledge which are attached to local modes of dwelling (Ingold, 2000). Anthropology and Sociology are devalued as knowledge, while local knowledge is not even worthy of consideration, according to the judge's assumptions. As further stated by the federal judge:

The expert [sanitation engineer] was very clear and showed a vast knowledge about the subject matter. He made a brilliant separation between the object of investigation and the aspirations of the suffering riverine population of the Jequitinhonha. However, it is necessary to highlight that the matter of attention here is the quality of the water and not the resolution of Sociological and Anthropological problems. (Juiz Federal Elísio Nascimento Batista Junior, Teófilo Otoni 06/05/2013).

As already discussed by many schools of thought since at least the 1960s, knowledge is situated (Zhouri and Oliveira, 2012). Technical reports are produced within specific conditions associated with the effects of relations of place, referring both to the more immediate context of enunciation and to the social space which structures inter-discursive relations. The Bourdieuan concept of field allows us to emphasize that positions in social space configure enunciative places from which certain constraints and potentialities become enrolled in discourses. This theoretical frame can help explain how, within ecological modernization, the adequacy paradigm (Zhouri and Oliveira, 2012) becomes operational. Within the adequacy paradigm, reports are made to adjust people and environment within a regulatory frame that emphasizes the inexorability of development projects defended in the name of broad and vague constituencies and entities, namely the nation, the public interest, and progress. Technical expertise in the environmental field prevails as discourse 
is shaped by disciplines such as Engineering and, in many cases, also Biology, Ecology and so on. Anthropology seems to be understood as a type of discourse that merely reproduces the "natives" point of view, therefore lacking the objectivity expected from a "technical" approach. The supposed objectivity of the natural sciences, on the other hand, effects a naturalization of knowledge - as if the knower were a mere conduit for self-evident facts. This cult of objectivity provides an ironic shadow to the ideological, gender and class bias of knowledge displayed in technical reports.

\section{Final Remarks}

Notions of space, population and "compulsory" displacement are central analytical categories of the modus operandi of state territorial and human population management. In a similar manner, categories of public interest and poverty are central to the justifications of development policies. Compulsory displacements are not caused by flaws or gaps related to the functioning of modern institutions, nor do they constitute "externalities" resulting from the developmentalist program. On the contrary, the multiplying of such experiences is an integral part both of the formation of nation-states, as well as their economic restructuring aimed at the promotion of development. As we can see from the case discussed in these pages, epistemological violence goes hand in hand with the implementation of megaprojects, even for those not subjected to compulsory relocation.

The people who live downstream the Irapé dam were not relocated. Indeed, they were not subject to any kind of state policy in relation to the dam, because the State recognizes as affected people only those who live in the area flooded of a dam. Since they live downstream, they continue in their places of origin, but those places are not the same as before because the river's flow is now under the direction of the energy company. Therefore, the knowledge they had developed over generations regarding the regularity of flows and the seasonal fluctuation of high water and low water, which had enabled them to practice floodplain agriculture (agricultura de vazante), no 
longer applies. Low and high waters now occur in an unexpected and irregular manner, subject to the whims of the dam operators. These communities now live in a modified environment, which impedes material reproduction, and the social organization of life and labour. It is in this sense that they can be identified as people subjected to epistemological violence and as "displaced in situ"as a result of the loss of their abilities developed in the historical circuit of social and environmental relations. They live now in a strange environment, over which they have no control and which they now struggle to comprehend. In light of this experience we can see how the Western dichotomy between society and nature effects epistemological violence against the lived knowledges of traditional and other rural communities who share a long-term connection to particular landscapes. From their perspective, water is not merely an objective 'environment' (nature), reducible to technical parameters that can be measured. Rather, water is part of a broader fabric of environment-plus-people, embodied in a local epistemology growing out of close association with a mode of livelihood. Though also Western in origin, Anthropological expertise has been applied in this analysis in an attempt to characterize this mode of livelihood and its epistemological basis. However, as the outcome of the case demonstrates, Anthropology's own epistemological legitimacy can be marginalized by the dominant technocratic standard of knowledge that lies at the heart of the ecological modernization paradigm.

Clearly the case study reveals the need for an epistemological critique of the regular usage of terms such as environmental impacts or problems within the environmental field. As already mentioned, the language of impact presupposes "the environment" as an objective reality independent and separated from society. As an object, the environment is analyzed in the light of scientific knowledge and technical assessment. The so-called "social impacts" of projects are reduced to areas limited by the project itself (the reservoir in the case of dams) as well as real estate matters, for which monetary compensation is a solution. The result is a kind of wilful blindness towards the local complexity of social organization and traditional 
forms of land tenure. Divisions among families and communities frequently occurs, since the administrative category of atingido (the affected people) considers individual landowners, mostly ignoring groups attached by familial and communitarian bonds. The role of expert knowledge in the licensing process is particularly relevant to the challenges faced by anthropologists, as the production of truth about the feasibility or effects of a certain enterprise puts different experts, institutions and fields of knowledge in dispute with one another. Professionals find themselves liable or accountable for their role in the production, consumption and distribution of discourses intended to be scientifically grounded and validated. Meanwhile, non-Western epistemologies and knowledge are not regarded as legitimate perceptions and discourses within the environmental field, constituting a form of epistemological violence that contributes conversely to the legitimacy of expropriation mechanisms as far as dams and other 'development' projects are concerned, hence perpetuating and increasing social inequalities.

\section{REFERENCES}

ACSELRAD, Henri; Selene Herculano and José Augusto Pádua (Eds.) (2004), Justiça Ambiental e Cidadania [Environmental Justice and Citizenship], Rio de Janeiro: Relume-Dumará, pp.294.

BERNO DE ALMEIDA, Alfredo Wagner; Zhouri, Andréa and Ioris, Antonio (2010), Capitalismo Globalizado e Recursos Territoriais [Globalized Capitalism and Territorial Resources], Rio de Janeiro: Lamparina, pp.350.

APPADURAI, Arjun (2004), Dimensōes Culturais da Globalização: a Modernidade Sem Peias [Cultural Dimensions Of Globalization; Modernity Without Limits], Lisboa: Teorema, pp. 237-63.

BLOEMER, Neusa Maria Sens (2001), "A hidrelétrica de campos novos: camponeses, migração compulsória e atuação do setor elétrico", in Maria José Reis \& Maria Sens Bloemer (Orgs.) Hidrelétricas e Populaçôes Locais, Editora da UFSC, Programa 
de Pós Graduação em Antropologia Social, pp. 93-118.

BOURDIEU, Pierre (1993 [1992]), Outline of a Theory of Practice, Cambridge: Cambridge University Press.

CARNEIRO, Eder Jurandir (2005), "A oligarquizaçâo da política ambiental mineira" [Oligarchization of environmental politics in mining], in Andréa Zhouri, Klemens Laschefski and Doralice Pereira (Eds.), A Insustentável Leveza da Politica Ambiental. Desenvolvimento e Conflitos Socioambientais [The Unsustainable Lightness of Environmental Politics: Development and SocioEnvironmental Conflicts], Belo Horizonte: Ed. Autêntica, pp. 65-88.

CORDEL DOS ATINGIDOS pela Barragem de Irapé [ Cordel of the Affected People from Irapé], 1997.

COSTA, Vanja de Azevedo (1991), "Saúde mental e modernização: Impactos da barragem de Tucurui sobre os pequenos produtores", in. Cadernos do CEAS Salvador, No. 133, pp. 51-67.

COUTO, Rosa Carmina de Sena (1999), "Saúde e projetos de desenvolvimento na Amazônia: a caso das hidrelétricas", Novos Cadernos do Naea, Vol. 2, No. 2, pp.

D'ALESSANDRO \& ASSOCIADOS (2001), Atendimento ao Pedido de Informaçóes Complementares ao EIA/RIMA - UHE Murta, Belo Horizonte.

ESCOBAR, Arturo (1995), Encountering Development, Princeton, NJ: Princeton University Press.

ESCOBAR, Arturo (2001), "Culture sits in places: Reflections on globalism and subaltern strategies of localization", Political Geography, Vol. 20, No. 2., pp. 139-174.

FELDMAN, Shelley, Charles Geisler \& Louise Silberling (2003), "Moving targets: Displacement, impoverishment and development", International Social Science Journal, Vol. 55, No. 175 , pp. 7-13.

GESTA-UFMG (2011), Impactos ds UHE Irapé para as comunidades a jusante. [Impacts of Irapé dam for the communities downstream ], pp.94.

INGOLD, Tim (2000), The Perception of the Environment: Essays in Livelihood, Dwelling and Skill, Lodon: Routledge. 
LI, Tania Murray (1999), “Compromising power: Development, culture and rule in Indonesia", Cultural Anthropology, Vol. 14, No. 3, pp. 295-322.

MIGNOLO, Walter (2004), "Os esplendores e as misérias da 'ciência': Colonialidade, geopolitica do conheci mento e pluri-versalidade epistémica" [The splendours and miseries of science: Coloniality, geopolitics of knowledge and epistemic pluri-versality], in Boaventura Souza Santos (Ed.), Conhecimento Prudente para uma Vida Decente [Wise Knowledge for a Decent Life], São Paulo: Cortez, pp. 667-710.

MIGNOLO, Walter (2008), "Desobediência epistêmica: A opção decolonial e o significado de identidade em politica" [Epistemic desobedience: The decolonial option and the meaning of identity in politics], Cadernos de Letras da UFF - Dossiê: Literatura, lingua e identidade [UFF Notebook of Language Dossier: Literature, Language and Identityl, 34Vol. 34, pp. $287-$ 324.

MOUFFE, Chantal (1999), "Por uma política da identidade nômade" [For a politics of nomad identity], Debate Feminista [Feminist Debate], Special Issue, Sáo Paulo: Companhia Melhoramentos.

NAJAR, Alberto (1990), "Malária, migrações e grandes projetos na Amazônia" [Malaria, migrations and large projects in the Amazon], Travessia: Revista do Migrante - As Migraçóes e as Barragens, Centro de Estudos Migratórios [Crossing: Journal of the Migrant - Migrations and Dams, Centre for Migration Studies], jan/april, pp. 33-38.

OLIVER-SMITH, Anthony (2006), "Displacement, resistance and the critique of development: From the grass roots to the global", in Chris de Wet (Ed.) Development-Induced Displacement: Problems, Policies and People, New York: Berghahn Books.

QUIJANO, Anibal (2002), "Colonialidade, poder, globalização e democracia” [Coloniality, power, globalization and democracy], Revista Novos Rumos [New Paths Journal], Vol. 37, No. 17, pp. 4-29.

RANCIÈRE, Jacques (1996), "O dissenso [Dissent]", in Newton 
Bignoto and Adauto Novaes (Eds,) A Crise da Razão [The Crisis of Reason], São Paulo: Cia das Letras, pp. 367-382. ROTHMAN, Franklin (2008), Vidas Alagadas: Conflitos Socioambientais, Licenciamento e Barragens [Flooded Lives: Socioenvironmental Conflicts, Licencing and Dams], Viçosa: Editora da Universidade Federal de Viçosa.

SACHS, Wolfgang (2001), "Globalization and Sustainability", World Summit Papers of the Heinrich-Böll Foudation, No. 6, Berlin: Heinrich-Böll Foudation .

SCOTT, James (1998), Seeing Like a State: How Certain Schemes to Improve Human Condition Have Failed, 2 New Haven: Yale University Press.

SIGAUD, Lygia, Ana Luiza Martins-Costa \& Ana Maria Daou (1987), "Expropriação do campesinato e concentração de terras em Sobradinho: Uma contribuição à análise dos efeitos da politica energética do Estado" [Expropriation and concentration of peasant lands in Sobradinho: A contribution to the analysis of the effects of State energy policy], Ciências Sociais Hoje [Social Sciences Todayl, São Paulo, pp. 214-290, Vértice, Editora dos Tribunais, ANPOCS.

SILVA, Patricia Pereira and Franklin Daniel Rothman (2011), "Press representation of social movements: Brazilian resistance to the Candonga Hydroelectric Dam", Journal of Latin American Studies, Vol. 43, No. 4, pp. 725-754.

SPERLING, Eduardo. Perícia. Processo 2006.38.13.012165-7, Classe: 7100-Ação Civil Pública. Plaintiff: Ministério Público Federal; Defendant: Companhia Energética de Minas Gerais — CEMIG. (s.D.) fls. 1393-1414.

ZHOURI, Andréa (2004), "Global-local Amazon politics: Conflicting paradigms in the rainforest campaign", Theory, Culture and Society, Vol. 21, No. 2, pp. 69-89.

ZHOURI, Andréa and Raquel Oliveira (2006 [2004]), "Industrial landscapes and the uprooting of local populations: social and environmental conflicts in hydroelectric projects", Irene Sofia Silva McGowan (Trans.) Teoria e Sociedade [Theory and Society], Vol. 1, available at http://socialsciences.scielo.org/pdf/s_tsoc/ 
v1nse/scs_a01.pdf

ZHOURI, Andréa and Raquel Oliveira (2009), "Developmental projects and violence in rural Brazil: The case of hydroelectric dams", in Sivaram Vemuri (Ed.), Connected Accountabilities: Environmental Justice and Global Citizenship, Oxford: InterDisciplinary Press, pp. 197-218, available at https:/www. interdisciplinarypress.net/online-store/ebooks/ethos-andmodern-life/connected-accountabilities

ZHOURI, Andréa, Raquel Oliveira \& Klemens Laschefski (2010), "A supressão da vazante e o início do vazio: Água e insegurança administrada no Vale do Jequitinhonha-MG" [The suppression of flow and the beginning of emptiness: Water and the administration of insecurity in Vale do Jequitinhonha-MG], Anuário Antropológico [Anthropological Annals], pp.23-53.

ZHOURI, Andréa and Raquel Oliveira (2012), "Development and environmental conflicts in Brazil: Challenges for anthropology and anthropologists", Vibrant, 9Vol. 9, No. 1, available at http:// www.vibrant.org.br/issues/v9n1/

ZHOURI, Andrea (2014), "Mapping environmental inequalities in Brazil: mining, environmental conflicts and impasses of mediation", In DesiguALdades.net Working Paper Series 75, Berlin, available at http://www.desigualdades.net/Resources/ Working_Paper/WP-Zhouri-Online.pdf

Notas

${ }^{1}$ Article first published in Waterlat-Gobacit Network Working Papers, ThematicArea Series - SATAMTA2 Water and Megaprojects. Working Paper Vol. 2, No 2, July, 2015. I am grateful to CNPq and FAPEMIG for supporting my research and participation at the VI Waterlat Meeting 2014. I also thank Alex Latta for his excellent English editing of this paper.

${ }^{2}$ According to Michael Cernea (quoted in Oliver-Smith, 2008: $3)$, "development projects are estimated to displace more than 
fifteen million people a year".

${ }^{3}$ Cerrado: is a type of plains community characterized by vegetation ranging from tropical broadleaf woodlands to scrublands, occurring in extensive areas of Brazil and in different areas of Minas Gerais; Caatinga: is a type of desert vegetation, and an ecoregion characterized by this vegetation in the interior of northeastern Brazil, including northern parts of Minas Gerais. It is a xeric shrubland and thorn forest, which consists primarily of small, thorny trees that shed their leaves seasonally; Mata Atlântica: the Atlantic Forest is a terrestrial biome and region which extends along the Atlantic coast of Brazil. In Minas Gerais. however, there is less than 7\% of Atlantic Forest still preserved.

${ }^{4}$ Cordel literature refers to cheap pamphlets, magazines, etc. which are displayed hanging along a cord on the sides of a newsstand.

${ }^{5}$ The original, in Portuguese: Em que pese o brilhante relatório...o relatório produzido pelo GESTA possuiu cunho muito mais sociológico e antropológico, do que técnico, sendo, inclusive, muito mais amplo do que o objeto da lide, faltando ao Grupo, conforme relatado pelo perito oficial, profissionais ou pesquisadores especializados em problemas de qualidade de água e impactos ambientais decorrentes de construção de represas. (grifos acrescidos)

${ }^{6}$ Nos esclarecimentos o perito foi bastante claro, demonstrando vasto conhecimento do assunto, e fez brilhante separação entre o objeto da pericia e as aspiraçóes da sofrida população ribeirinha do Jequitinhonha. Todavia, é preciso ressaltar que a lide está adstrita ao problema da qualidade da água e não da resolução de problemas de cunho sociológico e antropológico. (Juiz Federal Elísio Nascimento Batista Junior, Teófilo Otoni 06/05/2013)

Fecha de Recepción del Artículo: 5 de abril de 2018 Fecha de Aceptación: 15 de junio de 2018 